Roskladka N., Doctor in Economics, Professor

Roskladka A., Doctor in Economics, Professor Kyiv National University of Trade and Economics,

Kyiv, Ukraine

Stemplewska L., Doctor in Economics, Professor European University of Informatics and Economics in Warsaw, Warsaw, Poland

\title{
A FORECASTING OF TOURISM DEVELOPMENT IN UKRAINE BY THE DIFFERENT COMPUTER SYSTEMS
}

The tourism sector still maintains its ability to be an industry, which is intensively attracted by high developed countries and countries with emerging markets. The most important reason for this is that it is one of the quickly developing sectors in the world. This has highlighted the contribution of the tourism sector to the economics of the countries. With the impact of the World Tourism Organization's prediction (UNWTO, 2018) that the world tourism income will be 2 trillion dollars in 2020, each country has caused their own tourism supply potential to engage in the struggle to get a share of this or to enlarge the share they received.

According to the data presented in the Statistical Bulletin (Tourism Highlights, 2018), the number of international tourist arrivals in the world increased from 25 million persons in 1950 to 278 million in 1980, 530.8 million in 1995 and 1326.5 million persons in 2017 (Table 1).

Table 1

International tourist arrivals, 1990-2017, million

\begin{tabular}{|l|c|c|c|c|c|c|c|c|c|c|}
\hline \multirow{2}{*}{ Regions } & \multicolumn{9}{|c|}{ Years } & \multicolumn{2}{|c|}{$\begin{array}{c}\text { The rate of } \\
\text { change, 2017, } \\
\text { as \% till }\end{array}$} \\
\cline { 2 - 13 } & 1990 & 1995 & 2000 & 2005 & 2010 & 2015 & 2016 & 2017 & 1990 & 2010 \\
\hline World & 434.6 & 530.8 & 680.1 & 808.6 & 952.1 & 1195.0 & 1240.1 & 1326.5 & 305.2 & 139.6 \\
\hline Europe & 261.5 & 308.5 & 392.9 & 452.7 & 487.7 & 605.1 & 619.5 & 671.7 & 256.9 & 137.7 \\
\hline $\begin{array}{l}\text { Asia and } \\
\text { the Pacific }\end{array}$ & 55.9 & 82.0 & 110.4 & 154.1 & 208.2 & 284.1 & 306.0 & 323.1 & 578.0 & 155.2 \\
\hline Americas & 92.8 & 108.9 & 128.2 & 133.3 & 150.4 & 194.1 & 201.3 & 210.9 & 227.3 & 140.2 \\
\hline Africa & 14.8 & 18.7 & 26.2 & 34.8 & 50.4 & 53.6 & 57.7 & 62.7 & 423.6 & 124.4 \\
\hline $\begin{array}{l}\text { Middle } \\
\text { East }\end{array}$ & 9.6 & 12.7 & 22.4 & 33.7 & 55.4 & 58.1 & 55.6 & 58.1 & 605.2 & 104.9 \\
\hline
\end{tabular}

Source: Build by the authors based on the materials from UNWTO Tourism Highlights (2018) 
Despite all the hardships, tourism in Ukraine can and should become a sphere of realization of market mechanisms, a source of replenishment of state and local budgets, a means of public and full-time recreation and rehabilitation, as well as acquaintance with the historical and cultural heritage of our people and the state. Entrance tourism is a priority tourism destination for Ukraine and a significant factor in replenishing the currency revenues of the state treasury and creating additional jobs.

Authors have been builder a forecast of tourism development in Ukraine by modern forecasting systems and methods:

- an analytical forecasting model was built by the system of CurveExpert in the form of a polynomial function;

- analytical forecasting models were built by the system of computer algebra Maple in the form of piecewise linear and piecewise polynomial functions;

- numerical prediction models in the MathCAD system using different types of spline-interpolation and predictive functions have been constructed.

A comparative analysis of the results of forecasting in different systems was carried out. The results of the comparative analysis give confidence in the development of inbound tourism in Ukraine.

Based on research results and our opinion, for the effective development of tourism in Ukraine, it is necessary to take the following measures [1]:

- develop a methodology for integrated assessment of tourist resources, their classification and categorization, an effective marketing and management system;

- to provide state support to perspective applied research in the tourism industry;

- to improve the activities of Ukrainian tourist offices abroad;

- to study and implement progressive international experience of public administration and regulation of tourism industry;

- develop appropriate methodological recommendations for the further reformation of the training system of specialists-managers of the respective direction;

- to improve the competitiveness of the national tourism product through the improvement of the pricing management process at tourist enterprises.

The implementation of these recommendations will increase the efficiency of using the country's tourism potential, increase the 
competitiveness of tourism enterprises, increase budget revenues, reduce unemployment in the regions, and attract real investment in tourism.

\section{References}

1. Roskladka A., Roskladka N., Dluhopolskyi O., Kharlamova G., Kiziloglu M. Data analysis and forecasting of tourism development in Ukraine. Innovative Marketing. 2018. Volume 14, Issue 4. P. 19-33.

2. UNWTO Tourism Highlights: 2018 Edition. URL: https://www.eunwto.org/doi/pdf/10.18111/9789284419876. 